\title{
Lisa Botshon
}

University of Maine at Augusta

USA

DOI: 10.4312/elope.11.2.67-76

\section{From Blackboard to Blogs: Teaching English Literature in the Digital Age}

\author{
Summary
}

This essay explores the digitization of the English literature classroom and considers its current and future incarnations. What can web-based courses offer students and teachers of English literature? How might the use of blogs, Twitter, hypertexts, and course management systems like Blackboard, among other digital tools, change the structure and very nature of literature pedagogy? These questions are particularly important to consider as our society is transformed by digital technology and during a moment in which the internet has promised inclusivity and the democratization of culture. Concomitantly, however, the humanities have become vulnerable in our tech-focused era and digital divides among different social groups persist in higher education. Hence, we must deliberate our adoption and adaptation of digital pedagogy with great thoughtfulness and care.

Key words: digital pedagogy, digital divides, digitization of literature, literature pedagogy, web-based courses

\section{Od Blackboarda do blogov: Poučevanje angleške književnosti v digitalni dobi}

Povzetek

Prispevek obravnava digitalizacijo poučevanja angleške književnosti in raziskuje njene sedanje in prihodnje inkarnacije. Kaj lahko spletni pouk nudi študentom in učiteljem angleške književnosti? Kako bodo blogi, Twitter, hiperteksti, sistemi upravljanja z učnim okoljem, kakršen je Blackboard, in druga digitalna orodja spremenili zgradbo in in naravo poučevanja književnosti? To so vprašanja, ki so pomembna posebej v času, ko digitalna tehnologija spreminja družbo, internet pa obljublja večjo vključenost in demokratizacijo kulture. Kljub temu humanistika v tehnološko naravnani dobi postaja ranljiva, digitalni razkorak med različnimi družbenimi skupinami pa ostaja tudi v visokem šolstvu. Zato moramo natančno premisliti, kako uvajamo in prilagajamo digitalno pedagogiko.

Ključne besede: digitalna didaktika, digitalni razkorak, digitalizacija književnosti, didaktika književnosti, spletni pouk 


\section{From Blackboard to Blogs: Teaching English Literature in the Digital Age}

\section{Introduction}

In 2001 I taught my first Introduction to Literature course entirely online, employing a course management system called Blackboard, which is now ubiquitous in the United States. I never saw a single one of my students that spring, and I think all of us agreed by the end of the semester that the experience had been less than ideal. However, since that time, my university has whole-heartedly embraced digital technology as a pedagogical resource, including the regular offering of web-based English literature classes, and in 2011 I embarked on a new enterprise in which I taught an upperlevel literature seminar entirely online. This time, my tools were greatly improved, my students better prepared, and the course was much more successful. There are lingering questions, however, about such endeavors: Would my students have been better served by attending a live classroom in which we discussed the works in person? Or does learning in a virtual environment provide essential skills that contemporary educators should consider in order to prepare students for $21^{\text {st }}$-century success? This essay explores the digitization of the English literature classroom and considers its current and future incarnations. What can web-based courses offer students and teachers of English literature? How might the use of blogs, Twitter, Facebook, hypertexts, and course management systems like Blackboard, among other digital tools, change the structure and nature of English literature pedagogy? And how will the rise of digital technologies in our colleges and universities play out among different populations of students?

I must confess that I am still very much of a $20^{\text {th }}$-century educator. I take great pleasure in the classroom tools with which I learned to read, write, and think critically, and I still really like to use them - primitive tools like lecture, chalk and board, and print materials. I regularly employ YouTube, wikis, online readings, and web-based assignments, of course, but, overall, the technology I use for face-to-face teaching is fairly archaic. My $19^{\text {th }}$-century predecessors would find my face-to-face classrooms quite familiar, right down to the chalk dust. One might imagine that I suffer slightly from technophobia, then, resistant to a wholehearted embrace of $21^{\text {st }}$-century forms of technology. But this is far from the truth; like many faculty members of my generation, I have sought to incorporate technologies that might help to make my classroom a better space for learning.

So what might account for my reliance on primitive materials? The fact is, for a significant portion of the student body, these old tools do promote learning. We have thoughtful and provocative content; lively visuals; the sounds of our discussions and lectures; and a variety of methods to combine and manipulate them, with which we hope to reach a variety of learners. And even digital junkies will admit that the traditional form of the university, including its reliance on the same set of structures for centuries, has been tremendously successful, not only in replicating itself, but in helping students become more fully realized citizens. Moreover, as Mary McAleer Balkun warns, new technologies, as exciting and useful as they may be, come with their own sets of challenges, including sizable investments in time and training on the parts of both professors and students, divisions between haves and have-nots, questions about technological literacies, uncertainties about the pedagogical efficacy of new technologies, and the great speed with which new technologies change $(2011,15)$.

\section{Teaching Online: An Initial Foray}

Despite what some might consider my anachronistic tendencies, when I was first presented with 
the opportunity to teach my Introduction to Literature course online, I was enthusiastic about the possibilities such a format engendered. However, like many faculty members educated in the $20^{\text {th }}$ century, I continued to think of the traditional classroom as a paradigm for online learning: instead of lecturing and posing verbal questions, I posted background information in text format about the works we read and then sent written questions for the students to discuss. Students would debate the same issues as their face-to-face classmates via written discussion threads. Essays retained their traditional formats, as did other forms of evaluation, like tests and quizzes. Overall it seemed like a fairly painless - and promising - transformation.

During the spring of 2001, though, as I attempted to teach twenty online students the same sorts of materials I had been successfully teaching my face-to-face Introduction to Literature classes for three years, I realized that the course was not going well. It may be worth noting that I was teaching - and continue to teach - a population that comprises the majority of college students in the American higher education system, although they are underrepresented in journals and monographs: so-called non-traditional students, most of whom are adult women, often parents, who work at least part time. This population is typically a joy to teach; students generally care about their education and are sincere in their efforts to learn. Moreover, they are particularly keen to take classes that suit their busy lives, and web-based coursework, with its emphasis on asynchronous work, can feel like a better fit than face-to-face classes. However, non-traditional students are also more likely to be on the wrong side of the digital divide in contrast to their 18-year-old counterparts. In 2001, my students not only experienced challenges accessing computer hardware, software, and the internet - the latter of which is still an issue in rural Maine, where I teach - but, as Joanna Goode (2010) asserts about economically disadvantaged college students she studied in California, they also lacked the technological fluency that comes with growing up with computers at home. As Goode notes, "Computer expertise is more than a set of technical skills - it is a holistic conglomeration of interactions, experiences, and understandings with new technologies" (588). And this set of skills is highly impacted by issues such as gender and class. Despite my university's relatively early commitment to online education, then, our students' preparation for such developments was uneven at best.

The first tipoff to the negative trajectory of my Introduction to Literature class in 2001 was my discovery that within a month of making initial contact, exactly half the class had dropped out. The second was that two of the remaining students had begun to flame me on a regular basis. ${ }^{1}$ And the third was the emergence of flagrant plagiarism. What could I have been doing so wrong so as to engender such radical student abjection and misbehavior? I attempted to make reparations with more direction, a lot of midnight interventions, and a typical humble-teacher response: "Here's an open discussion board. You tell me what you want - even anonymously." But this did little to improve the quality of the class, and we limped along until the end of the semester, when the 10 remaining students and I heaved a collective (our first) sigh of relief.

Afterwards, I reviewed all the discussions and emails and final evaluations to see what I could uncover about and hopefully learn from the disaster that had been my first online course. What I found was discouraging. Several students had dropped out early in the semester because as easy to use as the software appeared to be, they were completely flummoxed by it. One of them had never even used email before and, despite many phone calls and pleas to visit my office, it took him a month to figure it out. By this time, it was much too late for him to start learning the ins and outs of Blackboard, not to mention to catch up on the readings and assignments. A couple of students lacked home or office access to a

"Flaming" is when one participant in an online discussion sends a derogatory comment to another person. In this case, the only derogatory comments were sent solely to me; thankfully, students in my class did not flame each other. 
computer and found it difficult to log on regularly from local libraries or parents' or friends' houses. A few students admitted that they thought an online course would be "easier" than traditional classrooms, and dropped out when it turned out to require a tremendous amount of reading and writing. Evidently, a majority of these students had signed up for the course without a clear picture of prerequisite skills or resources; this was a common occurrence in the early days of online teaching.

The flamers were a different matter. Sometimes students who send flaming remarks are just bullies, analogous to the occasional loudmouth that can crop up in a traditional classroom. ${ }^{2}$ But in this case, I was fairly sure that these students did not mean to sound derogatory; their messages were off tone because they were frustrated and they were not yet good enough writers to know how best to communicate with their professor solely through emails. Neither of these students had taken an online course before and both of them were used to talking to their professors in person when they had a problem. When I reached the flamers on the telephone, we were able to have much more productive conversations and the flaming ceased.

If you add up the list of problems my online class incited here, it is tempting to view them merely as the challenges of a new format and to dispense with them piecemeal: First make sure all the students know how to use the necessary digital tools; then ensure they have regular access to a computer with web access; finally, explain how emails to fellow students and professors should be appropriate in tone and content. And, undeniably, these directions would have improved certain aspects of my course. However, a larger problem superseded, and perhaps provoked, all the others: my online course was a pale, flat version of its traditional form and could not employ as many kinds of teaching and learning styles as even my $19^{\text {th }}$-century predecessor. Lacking sound (discussion), visuals (beyond the texts, a few images, and links), and in-person interaction, at which I excelled in the face-to-face classroom, the technology I employed actually limited the kind of teaching and learning that could take place. Moreover, instead of inspiring the formation of a virtual community, it alienated the student participants.

In retrospect, merely transferring my traditional course materials to an online format was destined to fail. Over a decade later, it is clear that this course's problems were indicative of the larger set of challenges faced by institutions of higher education during this period of technological growing pains. It's not just that I was trying to transfer my old pedagogical tools to new technology, but that I failed to understand what was essential about teaching online, and, moreover, that I was responsible for educating students who would require a new set of skills with which to negotiate a constantly morphing digital environment.

\section{New Directions in Digital Pedagogy}

Rena Palloff and Keith Pratt (2001) argue that in the cyber classroom, course development needs to focus on form, not content, which is a significant departure from traditional classroom techniques (152). According to Pallof and Pratt, professors must learn how to decenter themselves and act as directors rather than founts of information. Students, who often expect that the teacher is the only person from whom they can gain knowledge, should learn how to work and learn more collaboratively; they need to be "oriented to their new role and the ways in which learning occurs online" (153). Moreover, Pallof and Pratt assert, "Learning through the use of technology takes more than mastering a software program or feeling comfortable with the hardware being used. Students in online learning situations need to come to an awareness that learning through the use of technology significantly affects the learning process itself" (108). Palloff and Pratt were on the forefront of this thinking over a decade ago, before the age

For more on difficult online students see the work of Rena Palloff and Keith Pratt (2001). Their chapter "Online Classroom Dynamics" includes a section usefully entitled, "Working with Difficult Students." 
of Twitter, Facebook, and other transformations that have led to the myriad ways we now live our lives in cyberspace. Now, more than ever, it is imperative for institutions of higher education to help students become thoughtful citizens of the $21^{\text {st }}$ century. And that includes those of us who have always found pleasure in the delights of discussing a good book with a room full of engaged people.

In his recent book, Netsmart: How to Thrive Online, Howard Rheingold asserts that students "who understand the fundamentals of digital participation, online collaboration, informational credibility testing, and network awareness will be able to exert more control over their own fates than those who lack this lore" $(2012,2)$. There is some question, however, about the role of higher education to assist students in such endeavors. In their 2009 report The Future of Learning Institutions in a Digital Age, Cathy Davidson and David Theo Goldberg query the value of traditional learning institutions when

there are also many virtual sites where learning is happening[.] From young kids customizing Pokemon, to college students contributing to Wikipedia, to adults exchanging information about travel, restaurants, or housing via collaborative sites, learning is happening online, all the time, and in numbers far outstripping actual registrants in actual schools. What's more, they challenge our traditional institutions on almost every level: hierarchy of teacher and student, credentialing, ranking, disciplinary divides, segregation of "high" versus "low" culture, restriction of admission to those considered worthy of admission, and so forth (10).

As they note, there is a greater degree of fluidity and access to participation online than at traditional educational institutions. Davidson and Goldberg point out, too, that "digital technologies have dramatically encouraged self-learning. Web interfaces have made for less hierarchical and more horizontal modes of access," which has, in turn, "flattened out contributions to knowledge making... making them much less the function of a credentialed elite and increasingly collaboratively created" (24-5). If digital tools have made education in general more horizontal, then those of us in higher education must rethink how to make what we do more relevant to our students.

In part to answer this charge, in the spring of 2012, Harvard University and MIT announced a partnership, called edX, that hosts free online courses from both institutions. The platform, its creators argue, has the potential to improve face-to-face classes on the home campuses while giving students around the world access to a blue-ribbon education. Students who complete courses on the edX platform do not receive university credit, although they can earn certificates. This may be a new framework that higher education needs to help educate $21^{\text {st }}$-century citizens, but it will take some time before we understand the full ramifications of such an enterprise. Likewise, it is notable that neither Harvard University nor MIT has altered the requirements for its own students as a result of this new endeavor: elite students admitted to these institutions, in other words, continue to take classes in traditional formats, in face-to-face classrooms and laboratories with in-person professors, only dipping into Massively Open Online Courses (MOOCs) like edX for supplementary information when desired. In an article published in the Harvard Political Review, Harvard Provost Alan Garber makes a distinction between edX and traditional course offerings that are considered essential to a "top-notch quality education": "edX is not a replacement for Harvard's model of residential postsecondary education," Garber is quoted saying. "As we expand the number and variety of courses offered, we want to ensure that we maintain the rigor of the traditional classroom" (Finegold n. d.). Despite Garber's enthusiasm for the edX project, it is clear that he believes that greatest amount of "rigor" is found in the "traditional classroom." Additionally, even while a year after its initial founding nearly one million students had enrolled in edX courses, notably low completion rates raised questions about such a platform's efficacy. ${ }^{3}$

See, for example, Amna Hashmi and Cynthia Shih's (2013) piece in the Harvard Crimson, "The EdX Student." 


\section{Teaching English with Digital Tools}

Despite potential inequities and other challenges within and among digital teaching tools and techniques, pedagogies for teaching literature must evolve. Even those of us married to the bookclub paradigm of senior seminars must be mindful of the possibilities that the digital world opens up for pedagogy of all kinds. While there continues to be a danger of adopting technologies just because they're cool or potentially cost effective, there are numerous strategies that enhance and expand multiple learning experiences. Many new technologies allow us to have different kinds of conversations with students, incorporate richer and multilayered sources of materials into the classroom and in assignments, accommodate various learning styles and paces, and enable sustained collaborative learning among our students. And there is a proliferation of online forums $\mathrm{s}^{4}$ dedicated to helping those of us who entered the academy in the $20^{\text {th }}$ century to become more savvy to $21^{\text {st }}$ century tools - tools like Google Hangouts, which allows for synchronous meetings with online students (or colleagues, for that matter); screencasting software to make quick and easy videos; wikis that promote collaborative projects; and remind101, which helps students stay on track. However there are also tools that can change the way we read texts even in traditional classrooms. Applications like Google Lit Trips, ${ }^{5}$ Second Life, Google Ngrams, ${ }^{6}$ Wordles, and other digital tools can help us revamp discussions of the discipline itself, explore further what we study, and even rethink what we do when we study literature. However, as Trebor Scholz (2011) cautions, "Today, learning to learn through digital media implies that it simply isn't enough to have access to Wikipedia or YouTube or syllabi by MIT faculty and others; the urgent question becomes how we meaningfully and effectively learn with these tools, repositories, platforms, and all open education materials. How do we ignite student engagement, political and creative imagination, intellectual quest, and the desire for lifelong learning?" Thoughtful incorporation of digital tools is trickier than it seems, as this necessitates substantial investments of time and resources training, and, in many cases, retraining $20^{\text {th }}$-century educators to adopt and adapt $21^{\text {st }}$ century pedagogies. Moreover, as previously mentioned, because digital tools change very quickly in our era, it can be overwhelming for $20^{\text {th }}$-century educators to keep abreast of developments. Scholz asserts that because of the fast-paced changes that take place in the world of digital technologies, "we are all laggards." And while many of us educated in the previous century would have had no problem articulating standard techniques for teaching and learning two decades ago, today those standards have expanded so greatly that we would find it difficult to say with certainty what every $21^{\text {st }}$-century classroom should incorporate.

In the summer of 2014, as I revisit this essay, I recall a recent conversation with an instructional designer at my university. Her reply to my question about how I should best keep up with the latest developments, figure out which of those tools I should employ in my virtual and face-to-face classrooms, and learn to use those tools effectively, was a simple shrug. "Try one or two new things for each class," she instructs. Come to her for help if I can't figure it out. While I agree that unless one has, say, a grant or release time to change a course's delivery system wholesale or rethink a class via new technologies, a professor should make incremental alterations in the digital realm, this answer

I'm thinking of sites like Hybrid Pedagogy, an online journal, and HASTAC, the online Humanities, Arts, Sciences, and Technology Advanced Collaboratory.

5 Google Lit Trips are free downloadable files that mark the journeys of characters from famous literature on the surface of Google Earth. At each location along the journey there are placemarks with pop-up windows containing a variety of resources including relevant media, thought provoking discussion starters, and links to supplementary information about "real world" references made in that particular portion of the story. The focus is on creating engaging and relevant literary experiences for students.

6 This is a word-frequency charting software that draws from Google's huge collection of books. You type in a word, or a few words separated by commas, that you want to see mapped over time. In return, it provides you with a usage chart. See the HASTAC website for further discussion of how this might be employed in an English class. 
does not address the more global issue regarding how a university faculty member is meant to stay informed in the developments in his or her field(s) as well as in the rapidly changing world of digital tools. While some colleges and universities have worked out productive, structural ways to help professors rethink their approaches to digital pedagogies, many institutions, especially those with fewer resources, embark on these endeavors piecemeal, leaving the bulk of professional development efforts to individual faculty members themselves. Such a situation can cause a $20^{\text {th }}$-century professor to respond with paralysis. And yet Elizabeth Ellsworth (2011) reminds us that pedagogy always "needs to be worked out again and again":

The pedagogical set-up is a teaser, a guess, a speculation. It's a summoning of best guesses.... [T] he work of pedagogy is to tear teachers and students away from the curriculum's static objects of mourning, and challenge their loyalties to knowledge-objects - those ways of knowing that were created elsewhere at another time and to be made responsive to contemporary conditions.

Ellsworth advises that we proceed with a "confused awareness" that pedagogy may be productive, even if it is a cause of concern. Working fast and loose with new pedagogies, while uncomfortable, is not necessarily alien to the American professoriat, which has had little time to come up to speed technologically in the $21^{\text {st }}$ century. As with the example of my 2001 class, many of us have had to dive into new forms of pedagogy without knowing exactly what we were doing, and the learning curve for some of those efforts has been steep.

While I'm intrigued by the ever-expanding list of digital tools available to those of us who teach literature, and I employ many more than I did in 2001, I'm not always sure that deploying these tools will help my students reach already solid outcomes for literature classes like improving critical thinking, reading and writing skills. Hence, the current decade's iteration of my failed online course may not look radically different from its earlier cousin, although my recent attempts at teaching online are more thoughtful, designed to take into account a greater range of challenges, and thus more successful for both myself and my students. While I continue to employ Blackboard as the center of my course, my conveyed material and assignments are more diverse in format, employing screencasts instead of text-based lecture notes, and student video presentations in addition to textbased research, group keyword wiki projects, and multimedia portfolios. Colleagues of mine have made similar inroads using social media groups, YouTube videos, and other like tools to help create communities of virtual learners. These implements have made a great deal of difference in the look, feel, and process of our literature classes, and there is no doubt that they are more effective learning environments than the text-based desert that I created in 2001.

It is also worth mentioning that students today, even those in the non-traditional population, are likely to be more digitally savvy than a decade ago. In the meantime, universities have created tools to help students determine if they have what they need to take online classes, thus setting the stage for a better-equipped student population to enroll. In other words, we are all at least somewhat more prepared to teach and learn online.

\section{Final Thoughts}

As this essay goes to press in the fall of 2014, I am preparing the latest iteration of one of my nowregular online literature classes. I reflect on the last time I taught this class a couple of years ago and am satisfied with the few improvements that I intend to make this coming fall in order to promote a more dynamic, supportive, and challenging online classroom, including asynchronous video lectures by guest speakers, and Twitter assignments designed to connect my students with living 
authors. During the last version of this class, most of my students wrote in their evaluations that they enjoyed the course; they generally felt that they made progress in their reading and writing and, more specifically, in the material that comprised the focus of the class; in addition, they really liked the texts we read together. Only a handful withdrew, and not one of the students that completed the course failed.

Overall, especially in contrast to the 2001 class, this was a successful endeavor. Nonetheless, in my notes summing up this online class, I've written, "how great it would have been if we'd all been able to read these books together in person." This is illustrative of the loss of certain pleasures that are attendant in face-to-face teaching. As Richard Rose (2012) points out, online teaching not only requires new sets of instructor skills, but it also requires new sets of expectations. One of the primary losses in online teaching is the "constant validation" that successful professors can achieve in faceto-face classrooms. Rose asserts, for example, that "there is a world of difference between a warm face-to-face encounter and an e-mail - no matter how appreciative it might be. While there has been much discussion about how e-mail or even video interaction might not meet students' emotional and security needs, the emotional vacuum on the teacher's side has gone largely unnoticed." Moreover, online interactions with students can engender misjudgments. Instructors miss non-verbal cues that can help us understand students' ideas, their commitment to the class and even whether or not they are adequately understanding the course materials. Two of my now-favorite students, whom I first encountered in an online class, remained mere names associated with good online discussion posts and lively close readings until I met them in person and realized how smart, insightful, and congenial they were. While these students received good grades in my online course, I wasn't able to enjoy them and appreciate their progress as thinkers and writers until we shared the same space and time.

The other issue that continues to worry me about web-based course offerings at places like the University of Maine at Augusta, where I teach, is the digital divide. For example, our provost, unlike his counterpart at Harvard, would never claim that a MOOC is insufficiently rigorous for our students; in contrast, UMA encourages our students to enroll in MOOCs and other web-based courses when we cannot offer them what they need. Moreover, because web-based courses are perceived to be relatively cost-effective ways to offer our working-class commuting students degree programs, our faculty is urged to develop more and more online classes. Needless to say, such classes have not, and will not in the near future, become part of Harvard or other elite students' regular course loads. And this situation contributes to a larger irony as our less tech-savvy students at UMA and similar public universities pursue online degrees while their much more digitally prepared counterparts at Harvard and MIT continue to take primarily face-to-face classes.

I relate these ambivalences not to throw water on the subject, but as a way to register lingering concerns about the digitalization of teaching, especially teaching literature. I still believe that it is imperative that those of us teaching literature embrace digital tools - messy, confused, experimental as these pedagogies may be - but it is important that we not lose sight of the reasons we became excited by teaching literature in the first place: making connections with other readers, helping students reach "aha" moments in critical thinking, and creating communities of higher learning. Digital tools should be able to do all of these things and more: they can take us into virtual worlds of all kinds, provide us with data for conclusions that would have been unthinkable a generation ago, make space for new collaborations, and provide access to higher education to students for whom it would be otherwise prohibitive. Nonetheless, in order for all students to access these resources, higher education's investments in these endeavors must be rigorous. To ensure that all of our students are fully educated for the $21^{\text {st }}$ century, our institutions must make certain that its programs and 
educators are properly prepared to embark on this work. Moreover, in a cultural moment in which the humanities fields like English are regularly being scorned in favor of STEM (science, technology, engineering and math), which are touted as more "employable," those of us teaching literature in the U.S. are aware of our increasing vulnerability in higher education. ${ }^{7}$ And yet, as poet David Lehman asserts, "The ability of an educated populace to read critically, to write clearly, to think coherently and to retain knowledge... seems to be declining at a pace consonant with the rise of the Internet search engine and the autocorrect function in computer programs" $(2014,18)$. Hence, it is imperative that those of us teaching literature in this moment walk a fine line: we want to provide our students with the best of what studying literature can offer - the pleasure of reading, the importance of discoursing about the human condition with others, the conveyance of ideas, both old and new - and yet we also want to make sure that the students are able to harness new technologies with which to raise new questions and elevate our discussions. Teaching literature in our current digital age, then, is a complex endeavor without complete answers, but there is no turning back.

\section{References}

Balkun, Mary McAleer. 2011. “Teaching with Digital Media: Widening the Framework.” Transformations: The Journal of Inclusive Scholarship \& Pedagogy 22 (1): 15-24.

Davidson, Cathy, and David Theo Goldberg. 2012. The Future of Learning Institutions in a Digital Age. Cambridge, MA: MIT Press. http://mitpress.mit.edu/books/chapters/Future_of_Learning.pdf.

Ellsworth, Elizabeth. 2011. “The Wicked Problem of Pedagogy, An Afterword.” Learning Through Digital Media; Experiments in Technology and Pedagogy, March 31, 2011. http://learningthroughdigitalmedia.net/the-wickedproblem-of-pedagogy-an-afterword\#more-165. Accessed July 17, 2014,

Finegold, Sam. n.d. "EdX and the Harvard Undergraduate." Harvard Political Review. http://www.iop.harvard.edu/ edx-and-harvard-undergraduate. Accessed July 18, 2014.

Goode, Joanna. 2010. "Mind the Gap: The Digital Dimension of College Access." The Journal of Higher Education 81 (5): 583-618.

Hashmi, Amna, and Cynthia Shih. 2013. “The EdX Student.” The Harvard Crimson, May 30, 2013. http://www. thecrimson.com/article/2013/5/30/the-edX-student-international/?page=single. Accessed July 18, 2014.

HASTAC. Accessed May 4, 2012. http://hastac.org/.

Hybrid Pedagogy. Accessed April 30, 2012. http://www.hybridpedagogy.com/index.html.

Lehman, David. 2014. “Sing to Me, O Muse (But Keep it Brief).” New York Times Book Review, July 20: 18-9.

Palloff, Rena M., and Keith Pratt. 2001. Lessons from the Cyberspace Classroom: The Realities of Online Teaching. San Francisco, CA: Jossey-Bass Inc.

Rheingold, Howard. 2012. Net Smart: How To Thrive Online. Cambridge, MA: MIT Press.

Rose, Richard. 2012. "6 Tips for the Successful Online Teacher." THE Journal: Transforming Education Through Technology, June 18. http://thejournal.com/Articles/2012/06/18/6-must-have-skills-for-online-teachers. aspx?Page=1. Accessed July 30, 2014.

Schilling, Peter. 2003. "From Faculty to Student: The Evolution of Educational Technology." Transformations: Liberal Arts in the Digital Age 1 (2). http://www.colleges.org/trasnformations/index.php?q=node/view/40. Accessed May 2, 2012.

\footnotetext{
American news is filled with gloomy pronouncements of the end of the humanities, and front page articles in major news outlets like the New York Times regularly report on such crises in higher education. My own English Department has been asked to justify its existence several times in the last two years. For a broader perspective, see David Lehman's essay, in which he argues that "more than ever the humanities today stand in need of defense" $(2014,18)$.
} 
Scholz, R. Trebor, ed. 2011. "Introduction: Learning Through Digital Media; Experiments in Technology and Pedagogy.” Accessed July 17, 2014. http://learningthroughdigitalmedia.net/introduction-learning-throughdigital-media\#more-362. 